\title{
DAYA RACUN EKSTRAK UMBI GADUNG (Discorea hispida Dennst) TERHADAP HAMA KEONG EMAS (Pomacea sp.) DAN IKAN LELE (Clarias sp.) DI RUMAH KACA
}

\author{
Melshella Ferinda, Solikhin, Indriyati dan FX Susilo \\ Jurusan Agroteknologi, Fakultas Pertanian, Universitas Lampung \\ Jl. Prof. Dr. Soemantri Bojonegoro, No. 1 Bandar Lampung 35145 \\ Email : melshellaferinda@yahoo.com
}

\begin{abstract}
ABSTRAK
Penelitian ini bertujuan untuk mengetahui daya racun ekstrak umbi gadung (Discorea hispida Dennst) terhadap hama keong emas (Pomacea sp.) dan ikan lele (Clarias sp.). Penelitian ini dilakukan di Rumah Kaca Balai Proteksi Tanaman Pangan dan Hortikultura, Gadingrejo, Kabupaten Pringsewu pada bulan Maret sampai Mei 2016. Penelitian disusun dalam rancangan kelompok teracak sempurna (RKTS), dalam percobaan terhadap keong emas dengan 3 ulangan. Sebagai perlakuan adalah 7 taraf ekstrak umbi gadung yaitu P0 (0 g/l), P1 (5 g/l), P2 (10 g/l), P3 (15 g/l), P4 (20 g/l), P5 (25g/l) dan P6 (30 g/l). Percobaan terhadap ikan lele dengan 4 ulangan. Percobaan perlakuan adalah 5 taraf ekstrak umbi gadung yaitu P0 (0 g/l), P1 (2,5 g/l), P2 (5 $\mathrm{g} / \mathrm{l})$, P3 (7,5 g/l) dan P4 (10 g/l).Data diolah dan disajikan dalam bentuk tabel. Data dari uji daya racun tersebut dianalisis dengan analisis probit menggunakan SPSS version 23 for windows. Rata-rata daya racun (LT-50) dan (LC-50) ditentukan dengan taraf nyata 5\%. Hasil penelitian menunjukkan bahwa ekstrak umbi gadung bersifat lebih toksik terhadap ikan lele dibandingkan keong emas, hal ini ditunjukkan oleh besarnya LT-50 dan LC-50. Nilai LT-50 ekstrak umbi gadung terhadap keong emas pada konsentrasi $30 \mathrm{~g} / \mathrm{l}$ (2,5 hari) dan pada konsentrasi $5 \mathrm{~g} / 1$ (13,9 hari), sedangkan nilai LC-50nya adalah (0,024 g/l). Nilai LT-50 ekstrak umbi gadung terhadap ikan lele pada konsentrasi $10 \mathrm{~g} / 1$ (1,9 hari) dan pada konsentrasi 2,5 g/l (4,8 hari), sedangkan nilai LC-50nya adalah $(0,005 \mathrm{~g} / 1)$.
\end{abstract}

Kata kunci: ekstrak umbi gadung, ikan lele, keong emas, mortalitas.

\section{PENDAHULUAN}

Padi merupakan tanaman pokok yang penting bagi kehidupan manusia. Jika produktivitas padi menurun maka akan berdampak negatif bagi sektor-sektor pertanian. Salah satu faktor yang menyebabkan menurunnya produktivitas tanaman padi yaitu hama. Hama tanaman padi yang penyebarannya cukup luas dan banyak merusak pertanaman padi salah satunya adalah keong emas (Sadeli dkk., 1997).

Keong emas merupakan moluska yang ditetapkan sebagai organisme pengganggu tanaman (OPT) atau hama utama pada tanaman padi (Oryza sativa). Organisme ini berpotensi sebagai hama pada tanaman padi karena sawah merupakan habitat yang cocok bagi perkembangannya, sehingga keong emas dapat berkembang biak dengan cepat dan merusak tanaman padi dalam waktu yang cepat (Hendarsih \& Kurniawati, 2009).Perkembangan keong emas yang terus meningkat menyebabkan tanaman padi rusak dalam waktu yang cepat. Luas areal pertanaman padi yang dirusak keong emas pada tahun 2007 mencapai lebih dari 22.000 ha (Direktorat Perlindungan Tanaman Pangan, 2008). Oleh karena itu, mengingat pentingnya tanaman padi sehingga perlu alternatif pengedalian yang tidak menggunakan bahan-bahan kimia.

Salah satu alternatif pilihannya adalah penggunaan pestisida nabati. Pestisida nabati merupakan salah satu sarana pengendalian hama alternatif yang layak dikembangkan, karena termasuk pestisida yang ramah lingkungan dan cenderung memiliki dampak negatif yang kecil. Pestisida nabati yang digunakan dalam penelitian ini adalah tanaman umbi gadung (Susetyo dkk., 2008).

Tanaman gadung (Discorea hispida Dennst) merupakan anggota umbi-umbian yang mengandung zat gizi dan senyawa racun berbahaya. Selain mengandung zat gizi, umbi gadung juga mengandung alkaloid dioskorin dan seringkali bersifat toksik (Kardinan, 2005). Umbi gadung juga mengandung diosgenin yang juga termasuk golongan alkaloid, dioskorin bersifat lebih toksik dibanding dengan diosgenin (Pambayun, 2007).Menurut Adil (2010), Selain mengandung dioskorin, kandungan kimia lainya adalah saponin, amilim, $\mathrm{CaC}_{2} \mathrm{O}_{4}$, antidotum, besi, kalsium, lemak, garam, fosfat, protein dan vitamin B1. Menurut Pambayun (2007), umbi gadung juga 
mengandung asam sianida yang juga bersifat racun. Asam sianida merupakan racun bagi semua mahkluk hidup karena dapat menghambat pernapasan juga dapat mengakibatkan perkembangan sel yang tidak sempurna. Bagian dari tanaman gadung yang dimanfaatkan sebagai pestisida nabati adalah umbi gadung.

Penelitian ini bertujuan untuk mengetahui daya racun ekstrak umbi gadung (Discorea hispida Dennst) terhadap hama keong emas (Pomacea sp.) dan ikan lele (Clarias sp.).

\section{METODE PENELITIAN}

\section{Tempat dan Waktu Penelitian}

Percobaan ini dilaksanakan di RumahKaca Balai Proteksi Tanaman Pangan dan Hortikultura, Gadingrejo, Kabupaten Pringsewu pada bulan Maret sampai Mei 2016.

\section{Metode dan Pelaksanaan Penelitian}

Penelitian disusun dalam rancangan kelompok teracak sempurna (RKTS), dalam percobaan terhadap keong emas dengan 3 ulangan. Sebagai perlakuan adalah 7 taraf ekstrak umbi gadung yaitu $\mathrm{P}_{0}(0 \mathrm{~g} / \mathrm{l}), \mathrm{P}_{1}$ (5 g/l), $\mathrm{P}_{2}(10 \mathrm{~g} / \mathrm{l}), \mathrm{P}_{3}(15 \mathrm{~g} / \mathrm{l}), \mathrm{P}_{4}(20 \mathrm{~g} / \mathrm{l}), \mathrm{P}_{5}(25 \mathrm{~g} / \mathrm{l}) \mathrm{dan}$ $\mathrm{P}_{6}(30 \mathrm{~g} / \mathrm{l})$. Percobaan terhadap ikan lele dengan 4 ulangan. Percobaan perlakuan adalah 5 taraf ekstrak umbi gadung yaitu $\mathrm{P}_{0}(0 \mathrm{~g} / \mathrm{l}), \mathrm{P}_{1}(2,5 \mathrm{~g} / \mathrm{l}), \mathrm{P}_{2}(5 \mathrm{~g} / 1), \mathrm{P}_{3}$ $(7,5 \mathrm{~g} / 1)$ dan $\mathrm{P}_{4}(10 \mathrm{~g} / \mathrm{l})$. Setiap satuan percobaan pada keong emas menggunakan 10 ekor keong emas, sedangkan pada ikan lele menggunakan 5 ekor ikan lele ukuran 3-5 cm.

Pengambilan keong emas dan ikan lele dilakukan di persawahan dan kolam ikan lele Desa Tulong Agung, Kecamatan Gadingrejo, Kabupaten Pringsewu. Keong emas yang digunakan yaitu dengan ukuran cangkang 2 $\mathrm{cm}$ dan ikan lele yang digunakan berukuran 3-5 cm. Keong emas yang telah terkumpul dimasukkan kedalam ember yang berisi 2 liter air selama satu minggu untuk adaptasi. Selama proses adaptasi keong emas diberi pakan daun talas. Namun untuk ikan lele disiapkan 1 hari sebelum aplikasi dan diberi pakan pelet.

Ekstrak umbi gadung dibuat dengan bahan umbi gadung yang diambil dari Balai Proteksi Tanaman Pangan dan Hortikultura, Gadingrejo, Kabupaten Pringsewu. Umbi gadung yang telah dibersihkan kemudian ditimbang sesuai dengan perlakuan pada keong emas yaitu $0,5,10,15,20,25$ dan $30 \mathrm{~g}$, sedangkan perlakuan pada ikan lele yaitu $0,2,5,5,7,5,10 \mathrm{~g}$ Setelah ditimbang kemudian ditambahkan sebanyak $500 \mathrm{ml}$ air dan dihaluskan dengan menggunakan blender. Ekstrak umbi gadung kemudian disaring dan dimasukkan kedalam botol plastik.

Keong emas yang akan diuji diletakkan didalam ember yang berisi tanaman padi berkisar antara umur 15-30 hari setelah tanam. Setiap perlakuan masingmasing berisi 10 ekor keong emas. Ekstrak umbi gadung sebanyak $500 \mathrm{ml}$ kemudian ditambahkan kedalam ember yang berisi air $1500 \mathrm{ml}$ dan diaplikasikan pada keong emas sesuai perlakuan. Ikan lele yang akan diuji diletakkan didalam ember yang telah disiapkan. Ekstrak umbi gadung sebanyak $500 \mathrm{ml}$ dimasukkan ke dalam ember yang telah berisi air sebanyak $1500 \mathrm{ml}$. Ikan lele yang digunakan sebanyak 5 ekor berukuran $3-5 \mathrm{~cm}$ setiap perlakuan. Ekstrak umbi gadung diaplikasikan pada ikan lele dan selama proses pengamatan ikan lele diberi pakan pelet. Media uji yang telah diaplikasikan ekstrak umbi gadung ditutup dengan kain kasa untuk menghidari kemungkinan ikan lele keluar dari ember.

Pada penelitian ini pengamatan dilakukan dengan menghitung jumlah keong emas yang mati (mortalitas) akibat perlakuan. Pengamatan dilakukan setiap hari selama 2 minggu. Pengamatan pada ikan lele dilakukan dengan menghitung jumlah ikan lele yang mati pada setiap perlakuan dan dilakukan selama seminggu.

Data hasil penelitian akan diolah dan disajikan dalam bentuk tabel. Data dari uji daya racun tersebut dianalisis dengan analisis probit menggunakan SPSS version 23 for windows. Rata-rata daya racun (LT50) dan (LC-50) ditentukan dengan taraf nyata 5\%.

\section{HASIL DAN PEMBAHASAN}

\section{Toksisitas ekstrak umbi gadung terhadap keong emas (Pomacea sp.)}

Hasil pengamatan toksisitas dari ekstrak umbi gadung terhadap keong emas menunjukkan bahwa ekstrak umbi gadung bersifat toksik dan dapat menyebabkan kematian hama keong emas. Berikut adalah hasil analisis probit terhadap keong emas (Tabel 2).

Analisis probit menunjukkan bahwa nilai lethal time (LT-50) yang semakin kecil menyebabkan kecepatan daya bunuh ekstrak umbi gadung terhadap keong emas semakin tinggi. Kematian keong emas (Pomacea sp.) terjadi mulai hari ke-2 setelah aplikasi ekstrak umbi gadung dengan konsentrasi tertinggi $30 \mathrm{~g} /$ 1, sedangkan kematian keong emas yang terendah atau lebih lama terjadi pada hari ke-13 setelah aplikasi dengan konsentrasi terendah $5 \mathrm{~g} / \mathrm{l}$, kecuali pada kontrol tidak terjadi kematian keong emas. Hasil penelitian ini 
Tabel 2. Toksisitas ekstrak umbi gadung terhadap keong emas*

\begin{tabular}{lccc}
\hline \multirow{2}{*}{ Konsentrasi (g/l bobot segar umbi gadung) } & \multicolumn{3}{c}{ LT-50 (hari) } \\
\cline { 2 - 4 } & Rata-rata & Minimum & Maksimum \\
\hline 5 & 13,9 & 12,8 & 15,6 \\
10 & 13,3 & 12,1 & 15 \\
15 & 11,5 & 10,9 & 12 \\
20 & 8,1 & 6,4 & 9,2 \\
25 & 4,7 & 4,2 & 5,2 \\
30 & 2,5 & 2,2 & 2,8 \\
\hline
\end{tabular}

*) Hasil analisis probit dengan taraf nyata $=5 \%$

menunjukkan bahwa dengan pemberian konsentrasi ekstrak umbi gadung yang semakin tinggi terhadap keong emas maka daya bunuh keong emas semakin cepat.

\section{Toksisitas ekstrak umbi gadung terhadap ikan lele (Clarias sp.)}

Hasil pengamatan toksisitas dari ekstrak umbi gadung terhadap ikan lele (Clarias sp.) menunjukkan bahwa ekstrak umbi gadung bersifat sangat toksik dan dapat menyebabkan kematian yang lebih cepat. Berikut adalah hasil analisis probit terhadap ikan lele (Tabel 3). Analisis probit menunjukkan bahwa nilai lethal time (LT50) yang semakin kecil menyebabkan kecepatan daya bunuh ekstrak umbi gadung terhadap ikan lele semakin tinggi. Kematian ikan lele terjadi sejak 1 hari setelah aplikasi ekstrak umbi gadung. Hasil menunjukkan bahwa kematian semakin meningkat sampai hari ke-4 setelah aplikasi, kecuali pada kontrol tidak terjadi kematian ikan lele. Pada hari ke-4 setelah aplikasi, tidak terjadi lagi penambahan kematian ikan lele. Kematian ikan lele tertinggi atau lebih cepat terjadi pada perlakuan aplikasi ekstrak umbi gadung dengan konsentrasi $10 \mathrm{~g} / 1$, sedangkan kematian ikan lele terendah atau lebih lama diperoleh dari aplikasi ekstrak umbi gadung dengan konsentrasi $2,5 \mathrm{~g} / 1$.

Toksisitas (LC-50) ekstrak umbi gadung terhadap keong emas (Pomacea sp.) dan ikan lele (Clarias sp.)

Hasil pengamatan toksisitas ekstrak umbi gadung terhadap keong emas dan ikan lele menunjukkan bahwa ekstrak umbi gadung bersifat lebih toksik terhadap ikan lele dibandingkan keong emas. Berikut adalah hasil analisis probit terhadap keong emas dan ikan lele (Tabel $4)$.

Analisis probit menunjukkan bahwa nilai lethal concentration (LC-50) terhadap ikan lele lebih kecil dibandingkan nilai LC-50 pada keong emas, hal ini menujukkan bahwa daya racun ekstrak umbi gadung terhadap ikan lele lebih tinggi dibandingkan keong emas.

Tabel 3. Toksisitas ekstrak umbi gadung terhadap ikan lele*

\begin{tabular}{lccc}
\hline \multicolumn{2}{c}{$\begin{array}{c}\text { Konsentrasi (g/l bobot segar } \\
\text { umbi gadung) }\end{array}$} & Rata-rata & MT-50 (hari) \\
\cline { 2 - 4 } & 4,8 & 4,2 & Maksimum \\
\hline 2,5 & 3,9 & 3,4 & 5,3 \\
5 & 2,4 & 2 & 4,2 \\
7,5 & 1,9 & 1,2 & 2,7 \\
10 & & & 2,3 \\
\hline
\end{tabular}

*) Hasil analisis probit dengan taraf nyata $=5 \%$

Tabel 4. Toksisitas (LC-50) ekstrak umbi gadung terhadap keong emas dan ikan lele*

\begin{tabular}{lccc}
\hline \multirow{2}{*}{ Organisme Uji } & \multicolumn{3}{c}{ LC-50 (g/l) } \\
\cline { 2 - 4 } & Rata-rata & Minimum & Maksimum \\
\hline Keong emas & 0.024 & - & - \\
Ikan lele & 0,005 & 0,002 & 0,007 \\
\hline
\end{tabular}

*) Hasil analisis probit dengan taraf nyata $=5 \%$ 


\section{Pembahasan}

Hasil penelitian menunjukkan bahwa persentase kematian meningkat seiring dengan peningkatan konsentrasi ekstrak umbi gadung. Kematian keong emas mulai terjadi pada konsentrasi $30 \mathrm{~g} / 1$, sedangkan pada ikan lele kematian mulai terjadi pada konsentrasi $10 \mathrm{~g} / \mathrm{l}$.

Berdasarkan dari kedua hasil analisis probit terhadap mortalitas keong emas dan kematian ikan lele dapat terlihat jelas bahwa pengaruh dari aplikasi ekstrak umbi gadung lebih cepat mematikan ikan lele dibandingkan keong emas. Hal ini dilihat dari konsentrasi yang sama adalah $5 \mathrm{~g} / 1$ dan konsentrasi $10 \mathrm{~g} / 1$ pada mortalitas keong emas dan kematian ikan lele. Hasil analisis probit dari data yang diperoleh menunjukkan nilai LT-50 yang lebih kecil di masing-masing konsentrasi tertinggi, yaitu konsentrasi $30 \mathrm{~g} / \mathrm{l}$ untuk keong emas (LT$50=2,5$ hari) dan konsentrasi $10 \mathrm{~g} / 1$ untuk ikan lele (LT$50=1,9$ hari) menunjukkan aplikasi ekstrak umbi gadung terhadap ikan lele kecepatan daya bunuhnya lebih tinggi dibandingkan dengan keong emas yang kecepatan daya bunuhnya lebih rendah.

Nilai lethal concentration (LC-50) terhadap keong emas $(0,024 \mathrm{~g} / 1)$ dan terhadap ikan lele $(\mathrm{LC}-50=$ $0,005 \mathrm{~g} / \mathrm{l})$ menunjukkan bahwa daya bunuh ekstrak umbi gadung terhadap ikan lele lebih tinggi dibandingkan keong emas. Hal ini membuktikan senyawa umbi gadung besifat sangat toksik terhadap organisme non sasaran yaitu ikan lele dibandingkan dengan organisme sasaran yaitu keong emas.

Keong emas yang diberi perlakuan ekstrak umbi gadung menunjukkan adanya perubahan warna pada tubuh dibagian atas operculum berubah warna dari kuning terang menjadi kuning pucat kehitaman dan tubuh yang selalu mengeluarkan lendir dalam jumlah yang berlebihan, pada akhirnya bagian tubuh keong emas keluar dari cangkangnya. Menurut Musman et al., (2011), keong emas akan mengeluarkan cairan berupa lendir untuk menetralisirkan pengaruh racun dari tubuh, sehingga berlebihnya produksi lendir pada keong emas akan menghambat proses pernafasan dan kelamaan akan mati. Francis et al., (2002) juga menjelaskan bahwa terhambatnya proses pernapasan pada keong emas terjadi karena difusi oksigen melalui insang terhalangi oleh lendir tersebut.

Pada pengamatan terhadap ikan lele menunjukkan bahwa daya tahan ikan lele terhadap daya toksik ekstrak umbi gadung lebih rendah dibandingkan keong emas. Perubahan tingkah laku pada ikan lele disebabkan karena pemberian ekstrak umbi gadung. Perubahan yang dapat dilihat yaitu ikan aktif bergerak ketika diberi ekstrak umbi gadung dan ikan lele mencoba keluar dari media uji untuk menghindar dari air yang terkontaminasi racun. Ikan lele lebih sering muncul ke permukaan air sebagai upaya untuk mendapatkan udara, hal ini diduga akibat banyaknya racun dari ekstrak umbi gadung yang masuk ke tubuh baik melalui insang atau saluran pencernaan. Rudiyanti \& Ekasari (2009) juga menyatakan bahwa ikan yang terkena racun dapat diketahui dengan gerakan hiperaktif dan lebih sering berada di permukaan. Kemudian ikan bergerak lambat dan akhirnya menyebabkan kematian. Senyawa saponin yang terkandung dalam umbi gadung bersifat racun untuk ikan (Orwa et al., 2009). Menurut Reed et al., (1967), racun tumbuhan mempengaruhi insang sehingga ikan sulit bernafas.

Umbi gadung terbukti bersifat toksik terhadap keong emas dan ikan lele. Hasil analisis probit dari perbandingan data yang diperoleh menunjukkan nilai LT50 ekstrak umbi gadung dalam waktu 2 hari setelah aplikasi dengan konsentrasi tertinggi $30 \mathrm{~g} / \mathrm{l}$ sudah dapat mematikan keong emas, sedangkan pada ikan lele nilai LT-50 ekstrak umbi gadung dalam waktu 1 hari setelah aplikasi dengan konsentrasi tertinggi $10 \mathrm{~g} / 1$ sudah dapat mematikan ikan lele. Ini menunjukkan bahwa ekstrak umbi gadung cukup efektif untuk mematikan organisme sasaran yaitu keong emas. Namun terhadap organisme non sasaran yaitu ikan lele aplikasi ekstrak umbi gadung lebih berbahaya karena daya bunuhnya lebih tinggi. Kandungan dioskorin dan saponin yang ada dalam umbi gadung inilah yang bersifat toksik, sehingga menyebabkan terlepasnya tubuh keong emas dari cangkangnya kemudian berakhir dengan kematian, sedangkan pada ikan lele terjadinya perubahan kulit dengan timbulnya bercak merah pada tubuh ikan lele dan pada akhirnya mengakibatkan kematian.

Pada penelitian yang telah dilakukan, terlihat bahwa terjadi perubahan tingkah laku pada keong emas setelah aplikasi ekstrak umbi gadung. Perubahan yang terjadi adalah pergerakan keong emas yang mula-mula aktif menjadi sangat lambat. Nafsu makan keong emas mula-mula aktif menjadi berkurang bahkan sampai tidak ada nafsu untuk makan lagi.Perubahan selanjutnya adalah pada hari ke-2 setelah aplikasi dengan konsentrasi $30 \mathrm{~g} / 1$ ada salah satu keong emas yang mati dan terapung di atas permukaan air. Perubahan morfologi pada keong emas yang mati yaitu operculum terbuka dan mengalami perubahan warna pada tubuh di bagian atas operculum dari warna kuning terang menjadi coklat kehitaman. Tubuh keong emas mengeluarkan lendir secara terus menerus sehingga dapat menghambat proses pernapasan dan menyebabkan keluarnya tubuh keong emas dari cangkang. Hasil ini didukung oleh Laoh et al., (2013) yang menyatakan bahwa semakin banyak senyawa pestisida nabati yang masuk dalam tubuh 
keong emas maka semakin banyak jaringan yang dirusak sehingga menyebabkan kematian. Keong emas yang diberi perlakuan senyawa kimia akan mengakibatkan pergerakan menjadi lambat, nafsu makan berkurang, mengeluarkan lendir dan tubuh keluar dari cangkang dan mati.

Pada penelitian yang telah dilakukan, terlihat bahwa terjadi perubahan tingkah laku pada ikan lele setelah aplikasi ekstrak umbi gadung. Perubahan tingkah laku terlihat dari 3 jam setelah aplikasi yaitu keaktifan dalam bergerak berkurang dan tidak ada lagi nafsu untuk makan. Perubahan juga terjadi pada tubuh ikan lele terlihat dengan perubahan kulit yang mulai mengelupas dan muncul bercak merah pada tubuh ikan lele. Perubahan yang terjadi pada ikan lele yang mati setelah aplikasi ekstrak umbi gadung yaitu ikan lele terapung di atas permukaan air, tubuh menjadi kaku, perubahan kulit

\section{KESIMPULAN}

Berdasarkan hasil penelitian dapat disimpulkan bahwa ekstrak umbi gadung bersifat toksik dan menyebabkan kematian baik pada hama keong emas maupun ikan lele. Semakin tinggi konsentrasi ekstrak umbi gadung akan mengakibatkan daya bunuh terhadap hama keong emas dan ikan lele yang lebih cepat, hal ini ditunjukkan oleh besarnya LT-50 dan LC-50. Nilai LT50 ekstrak umbi gadung terhadap keong emas pada konsentrasi $30 \mathrm{~g} / 1$ (2,5 hari) dan pada konsentrasi $5 \mathrm{~g} / 1$ (13,9 hari), sedangkan nilai LC-50nya adalah $(0,024 \mathrm{~g} /$ 1). Nilai LT-50 ekstrak umbi gadung terhadap ikan lele pada konsentrasi $10 \mathrm{~g} / 1$ (1,9 hari) dan pada konsentrasi $2,5 \mathrm{~g} / 1$ (4,8 hari), sedangkan nilai LC-50nya adalah $(0,005$ $\mathrm{g} / \mathrm{l})$.

\section{DAFTAR PUSTAKA}

Adil, W. H. 2010. Gadung, Manfaat dan Perbanyakannya Secara In Vitro. 19 September 2015. http://pustaka.litbang.deptan.go.id/ publikasi/wr326106.pdf.

Direktorat Perlindungan Tanaman Pangan. 2008. Luas Serangan Siput Murbai pada Tanaman Padi Tahun 1997-2006, Rerata 10 Tahun dan Tahun 2007. Direktorat Jenderal Tanaman Pangan. Jakarta. yang mengelupas dan adanya bercak merah pada tubuh ikan lele.

Hasil penelitian menunjukkan bahwa ekstrak umbi gadung lebih berbahaya terhadap organisme non sasaran yaitu ikan lele dibandingkan organisme sasaran yaitu keong emas. Menurut Pambayun (2007), umbi gadung mengandung asam sianida yang bersifat racun bagi semua makhluk hidup karena dapat menghambat pernapasan juga dapat mengakibatkan perkembangan sel yang tidak sempurna. Hal ini membuktikan bahwa kandungan dalam umbi gadung bersifat toksik. Toksisitas ini lah yang dapat mematikan keong emas dan ikanlele, makauntuk itu pestisidanabati umbi gadung tidak dapat diaplikasikan pada pola tanam sistem minapadi, karena dapat mematikan organisme non sasaran yaitu ikan Iele. Pestisida nabati umbi gadung hanya dapat diaplikasikan pada tanaman padi yang tidak menggunakan sistem minapadi .

Francis, G., Z. Keren, H.P.S. Makkar, K. \&Becker. 2002. The Biological Action of Saponins in Animal Systems: A Review. British Journal of Nutrition, 88:587-605.

Hendarsih, S. \& Kurniawati, N. 2009. Keong Mas Dari Hewan Peliharaan Menjadi Hama Utama Padi sawah. Balai Penelitian Tanaman Padi. Subang. Di akses 19 September 2015. www.litbang.deptan.go.id/spesial /padi/ bbpadi_2009_itp_14.pdf.

Kardinan, A. 2005. Pestisida Nabati: Ramuan dan Aplikasi. Penerbit Swadaya. Jakarta.

Laoh, H., Rusli, R. \& Riadi, P. 2013. Pemberian Beberapa Dosis Tepung Biji Pinang (Areca catechu L.) Lokal Riau Untuk Mengendalikan Hama Keong Emas (Pomacea canaliculata L.) Pada Tanaman Padi. J. Hpt. 1(2): 1-8.

Musman, M. 2009. The Potency of Penteut Ie (Achehnese Barringtonia racemosa (L.)Spreng) as Molluscicide of Pomacea Species (Ampullariidae). In Abidin etal. (eds.). Understanding Disaster and Environmental Issues with Science and Engineering towards Sustainable Development. Proceeding The International Conference on Natural and Environmental Sciences 2009 (ICONES ’09). Banda Aceh. 
Musman, M. Sofia \& Kurnianda, V. 2011. Selektifitas fraksi $R f<0,5$ ekstrak etil asetat (EtOAc) biji putat air (Barringtonia racemosa) terhadap keong mas (Pomacea canaliculata) dan ikan lele lokal (Clarias batracus). Jurnal Depik, 1(2): 99-102.

Orwa, C., A. Mutua, R. Kindt, R. Jamnadass \& A. Simons. 2009. Barringtonia racemosa (L.) Spreng Lecythidaceae, Agroforestry Database: a treereference and selection guide version 4.0. Diakses 02 Oktober 2016. http:// www.worldagroforestry.org/af/treedb.

Pambayun, R. 2007. Kiat Sukses Teknologi Pengolahan Umbi Gadung. Ardana Media. Yogyakarta.

Reed, W., J. Burchard, A.J. Hopson, J. Jenness, L.\& Yaro. 1967. Fish and Fisheries of Northern Nigeria publication. Ministry of Agriculture press Northern Nigeria. Pp. 201-202.

Rudiyanti, S., A.D. \&Ekasari. 2009. Pertumbuhan Dan Survival Rate Ikan Mas (Cyprinus carpio Linn) Pada Berbagai Konsentrasi Pestisida Regent 0,3 g. Jurnal Saintek Perikanan, 5(1):39-47.

Sadeli, S. Budiman, S. Djoko, R.D. Mei \& Dimyanti, A. 1997. Petunjuk Teknis Usaha Tani Padi Tanam Benih Langsung (TABELA). BPTP Lembang.

Susetyo, T. Ruswandi \& E. Purwanti. 2008. Teknologi Pengendalian Organisme Pengganggu Tumbuhan (OPT) Ramah Lingkungan. Direktorat Perlindungan Tanaman Pangan. Jakarta. 